Article

\title{
The Interactions of CPP-ACP with Saliva
}

\author{
Noorjahan Laila Huq, Helen Myroforidis, Keith J. Cross, David P. Stanton, Paul D. Veith, \\ Brent R. Ward and Eric C. Reynolds *
}

Oral Health Cooperative Research Centre, Melbourne Dental School, Bio21 Institute, The University of Melbourne, 720 Swanston Street, Melbourne 3010, Australia; laila@unimelb.edu.au (N.L.H.); helen_myroforidis@hotmail.com (H.M.); keith.cross@unimelb.edu.au (K.J.C.); dstanton@unimelb.edu.au (D.P.S.); pdv@unimelb.edu.au (P.D.V.); brentrw@unimelb.edu.au (B.R.W.)

* Correspondence: e.reynolds@unimelb.edu.au; Tel.: +61-3-9341-1547

Academic Editor: Eva Freisinger

Received: 14 March 2016; Accepted: 24 May 2016; Published: 9 June 2016

\begin{abstract}
The repair of early dental caries lesions has been demonstrated by the application of the remineralisation technology based on casein phosphopeptide-stabilised amorphous calcium phosphate complexes (CPP-ACP). These complexes consist of an amorphous calcium phosphate mineral phase stabilised and encapsulated by the self-assembly of milk-derived phosphopeptides. During topical application of CPP-ACP complexes in the oral cavity, the CPP encounters the enamel pellicle consisting of salivary proteins and peptides. However the interactions of the CPP with the enamel salivary pellicle are not known. The studies presented here reveal that the predominant peptides of $\mathrm{CPP}-\mathrm{ACP}$ complexes do interact with specific salivary proteins and peptides of the enamel pellicle, and provide a mechanism by which the CPP-ACP complexes are localised at the tooth surface to promote remineralisation.
\end{abstract}

Keywords: saliva; pellicle; casein phosphopeptide; enamel

\section{Introduction}

Dental caries is one of the most common oral diseases [1,2]. Aciduric and acidogenic bacteria, in plaque, ferment dietary sugars to produce organic acids that demineralise enamel and initiate dental caries [3]. At early stages of dental caries, the hydroxyapatite mineral loss is reversible [2]. Any products that prevent enamel demineralisation and promote remineralisation are described as exhibiting anticaries activity. Dairy products, such as milk and cheese have been reported to exhibit anticariogenic properties $[4,5]$. The phosphoprotein caseins complexed with calcium and phosphate are the components of dairy products responsible for this anticariogenic activity [6]. The phosphopeptides of casein derived from enzymic hydrolysis are known as casein phosphopeptides (CPP). These bind calcium and phosphate ions through their multiple phosphoseryl residues in an amorphous, bioavailable form [7-9]. The binding to mineral ions is $\mathrm{pH}$ dependent and increases from pH 4.0 to a maximum at $\mathrm{pH} 9.0[10,11]$.

The resulting complexes are known as casein phosphopeptide amorphous calcium phosphate (CPP-ACP) [12]. The complexes incorporating fluoride are known as casein phosphopeptide amorphous calcium fluoride phosphate (CPP-ACFP) [13,14].

CPP-ACP complexes have been reported to inhibit enamel demineralisation and promote remineralisation of early enamel subsurface lesions [15-18]. They have been commercialised as Recaldent $^{\mathrm{TM}}$ and are currently being added to sugar-free chewing gums (Trident $\mathrm{X}$ tra Care (Americas), Recaldent (Japan)) and dental crème (Tooth Mousse and Tooth Mousse Plus (Europe and Australia), MI Paste and MI Paste Plus (Japan and Americas)) [15].

In the oral cavity the tooth mineral surface is covered by a layer of salivary proteins, known as the acquired enamel pellicle whose proteome and peptidome have been recently characterised [19-21]. 
During topical application of the CPP-ACP complexes, the CPP first encounter the enamel pellicle. However the interactions of the $\mathrm{CPP}$ with the enamel salivary pellicle have not been investigated.

The aim of the study was to investigate the molecular interactions between $\mathrm{CPP}-\mathrm{ACP}$ complexes, enamel hydroxyapatite, and salivary proteins that would occur during topical application of CPP-ACP in the oral cavity. In this study, a series of experiments revealed that two predominant peptides from CPP-ACP (Figure 1) interact with specific salivary proteins including several that are found within the enamel pellicle.

(1) Argi-Glu-Leu-Glu-Glu-Leu-Asn-Val-Pro-Gly-Glu-Ile-Val-Glu-Ser(P)-Leu$\underline{(\operatorname{Ser}(\mathbf{P})-)_{3}}{ }_{3}(\mathrm{Glu}-)_{2}$ Ser-Ile-Thr-Arg ${ }^{25} \quad \beta-C N(1-25)$

(2) Gln ${ }^{59}-M e t-G l u-A l a-G l u-S e r(P)-I l e-(S e r(P)-)_{3}(G l u-)_{2} I l e-V a l-P r o-A s n-S e r(P)-V a l-G l u-$ Gln-Lys ${ }^{79} \alpha s 1-C N(59-79)$

Figure 1. The sequences of the two major casein tryptic phosphopeptides with the calcium phosphate binding-motif underlined are depicted using the three-letter code.

\section{Results}

Several in vitro approaches were considered to identify the salivary proteins and peptides that bind to both HA and to CPP. In the first strategy, the two predominant peptides of CPP, $\alpha_{\mathrm{S}_{1}-\mathrm{CN}}$ (59-79) and $\beta-C N(1-25)$, were immobilised separately onto Sepharose $4 \mathrm{~B}$ for the identification of the salivary peptides and proteins by affinity chromatography. As an alternative strategy, the CPP were immobilised onto HA crystals for identification of bound CPP using SDS-PAGE. A third approach involved adsorbing selected salivary proteins in 96 well plates for the indirect detection by antibodies that recognise the salivary protein-bound CPP.

\section{A Diverse Range of Salivary Proteins and Peptides Bind to the Predominant Peptides of CPP-ACP}

Affinity chromatography was used to capture the salivary proteins that bound to either $\alpha_{\mathrm{S} 1}-\mathrm{CN}$ (59-79) and $\beta-C N(1-25)$. Whole or parotid saliva was applied to the $\alpha_{\mathrm{S1}}-\mathrm{CN}$ (59-79) or $\beta-\mathrm{CN}(1-25)$ affinity columns following equilibration with $20 \mathrm{mM}$ Tris- $\mathrm{HCl} \mathrm{pH} \mathrm{8.} \mathrm{After} \mathrm{removal} \mathrm{of} \mathrm{the} \mathrm{unbound}$ proteins, the bound salivary proteins and peptides were then eluted with a step-gradient of increasing $\mathrm{NaCl}(0.25-1 \mathrm{M})$ in $20 \mathrm{mM}$ Tris- $\mathrm{HCl} \mathrm{pH} 8$ (Table S1). A blank Sepharose $4 \mathrm{~B}$ column was used as a control. No salivary proteins or peptides were detected in the $0.25-1 \mathrm{M} \mathrm{NaCl}$ eluent of the control column. The affinities of the salivary proteins/peptides bound onto the immobilized CPP columns were qualitatively assessed based on the $\mathrm{NaCl}$ concentration required to dissociate the protein. A greater number of proteins from both whole and parotid saliva were identified as interacting with $\alpha_{S 1}-\mathrm{CN}$ (59-79) compared with $\beta-\mathrm{CN}(1-25)$ (Tables S2 and S3). Proteins that bound to both $\alpha_{\mathrm{S} 1}-\mathrm{CN}$ (59-79) and $\beta-\mathrm{CN}(1-25)$ included amylase, IgA, histatin, cystatin S, cystatin SN, mucin 7, kallikrein, prolactin inducible protein, Protein S-100-A9, submaxillary gland androgen-related protein 3 homolog B (Tables S2 and S3).

Salivary proteins that eluted from $\alpha_{\mathrm{S} 1}-\mathrm{CN}$ (59-79) only with $1 \mathrm{M} \mathrm{NaCl}$ include polymeric immunoglobulin receptor (pIgR) ( $M w \sim 65,965 ; \mathrm{pI} 5.14)$, carbonic anhydrase VI ( $M w \sim 33,569 ; \mathrm{pI} 6.41)$, Lysozyme C ( $M w \sim 14,700 ;$ pI 9.28), and immunoglobulin J ( $M w \sim 15,594 ;$ pI 4.59). These tightly bound proteins have masses ranging from 14 to $65 \mathrm{kDa}$ and $\mathrm{pI}$ from 4.59 to 9.28 . Salivary peptides within the range of $2-5 \mathrm{kDa}$ bound to both $\alpha_{\mathrm{S1}}-\mathrm{CN}(59-79)$ and $\beta-\mathrm{CN}(1-25)$.

Another approach was adopted to identify the salivary proteins from whole saliva that adsorbed to HA pre-coated with either $\alpha_{\mathrm{S} 1}-\mathrm{CN}$ (59-79) and $\beta-\mathrm{CN}(1-25)$. The bound and unbound salivary proteins were visualised using SDS-PAGE (Figure 2). Observed differences in concentrations of salivary 
proteins bound to $\alpha_{S 1}-\mathrm{CN}$ (59-79) or $\beta-\mathrm{CN}(1-25)$ immobilised onto HA indicate different affinities. The higher-mass salivary proteins are observed to interact more strongly with $\alpha_{S 1}-\mathrm{CN}$ (59-79)-coated HA as shown in lane 4 (Figure 2). In contrast the low-mass salivary peptides including statherin, histatin 1 and defensin interacted more strongly with the $\beta-\mathrm{CN}(1-25)$-coated HA as shown in Lane 2 (Figure 2).

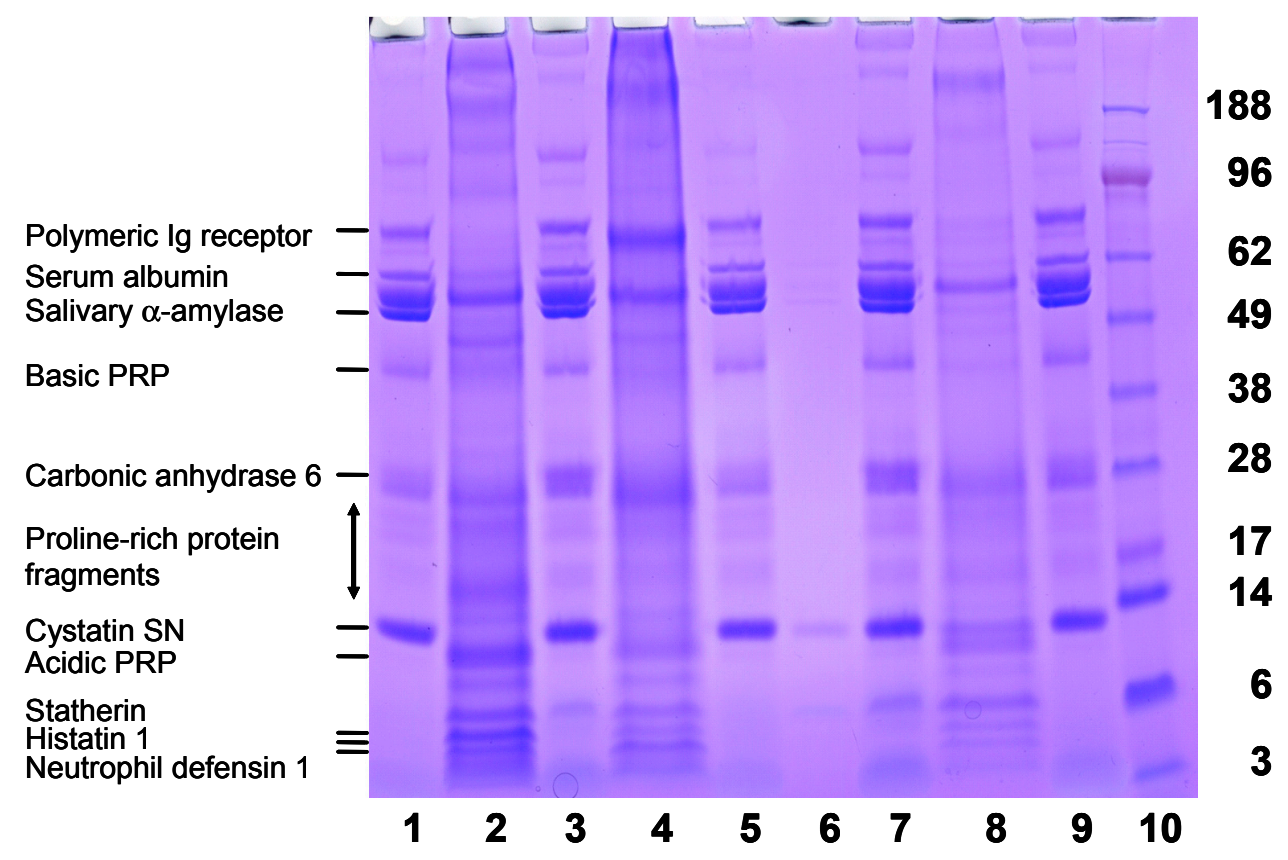

Figure 2. SDS-PAGE profile of salivary proteins derived from whole saliva (WS) bound to casein phosphopeptides (CPP)-coated or uncoated HA. Lane 1: Salivary proteins not bound to $\beta-\mathrm{CN}(1-25)$. Lane 2: Salivary proteins bound to $\beta-\mathrm{CN}(1-25)$. Lane 3: WS. Lane 4: Salivary proteins bound to $\alpha_{\mathrm{S} 1}-\mathrm{CN}$ (59-79). Lane 5: Salivary proteins not bound to $\alpha_{\mathrm{S} 1}-\mathrm{CN}$ (59-79). Lane 6: WS diluted 1 in 20. Lane 7: WS. Lane 8: Salivary proteins bound to uncoated HA control. Lane 9: Salivary proteins not bound to uncoated HA. Lane 10: Prestained markers.

As a control the predominant salivary peptides and proteins derived from whole saliva that bound to HA not coated with the CPP are shown in Lane 8 of Figure 2. These salivary proteins that bound directly to HA were consistent with previous reports on the adsorbed salivary proteins of human acquired enamel pellicle [21-28]. The proteins identified included: bound mucins 5 and 7, amylase, albumin, sIgA, statherin, cystatins, lysozyme, carbonic anhydrase, lactoferrin, lactoperoxidase, histatins, and proline-rich proteins. The peptides identified were: statherin, histatin family, and the proline-rich protein family. The prior adsorption of the CPP $\left(\alpha_{\mathrm{S} 1}-\mathrm{CN}(59-79)\right.$ and $\left.\beta-\mathrm{CN}(1-25)\right)$ onto HA produced a significant change in the profile of salivary proteins bound (Figure 2 Lane 2 and Lane 4 compared with the control Lane 8). This approach allowed the major proteins/peptides from saliva bound by the CPP to be identified.

These two approaches (CPP-sepharose and CPP-HA) identified salivary proteins and peptides that bound to $\alpha_{S 1}-\mathrm{CN}$ (59-79) and $\beta-\mathrm{CN}(1-25)$ that were individually immobilised onto Sepharose $4 \mathrm{~B}$ matrix or onto HA particles. Analysis of the complete dataset from both approaches confirmed that CPP interacted with selected salivary proteins and peptides known to be found in human acquired enamel pellicle (Tables 1 and 2) [21-28]. The CPP were found to bind to specific salivary pellicle peptides from the statherin, proline-rich protein and histatin families. Salivary proteins and peptides of pellicle found to bind to CPP exhibited a range of masses and $\mathrm{pI}$ values (Figure 3, Tables 1 and 2). 


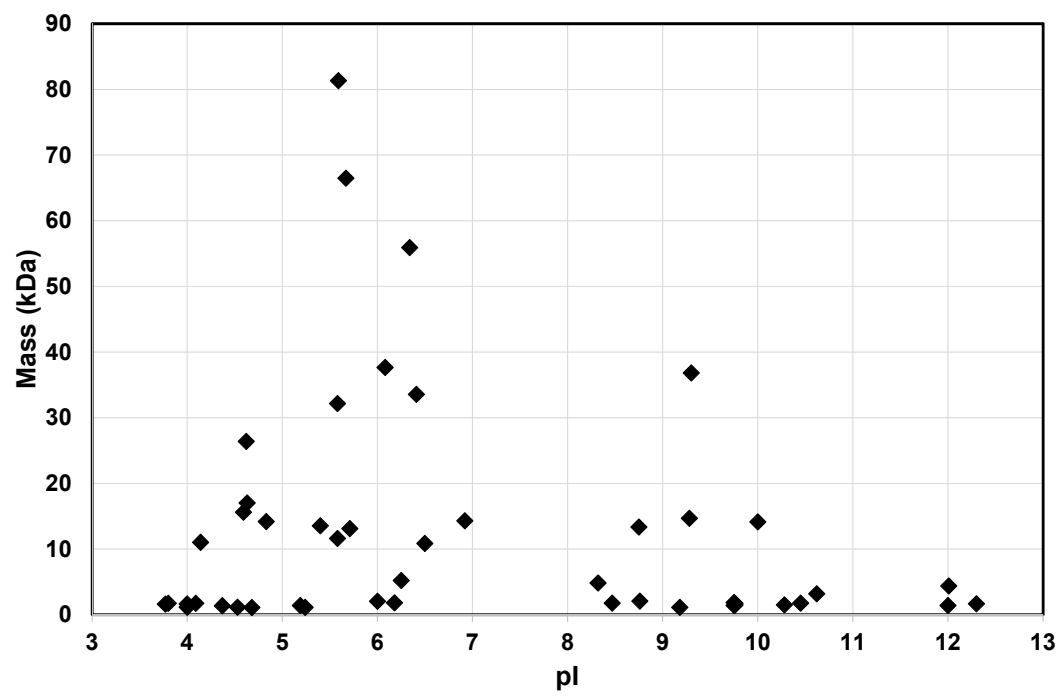

Figure 3. Mass and $\mathrm{pI}$ distribution of salivary proteins and peptides of human acquired enamel pellicle that bind to $\mathrm{CPP}\left(\alpha_{\mathrm{S} 1}-\mathrm{CN}(59-79), \beta-\mathrm{CN}(1-25)\right)$.

Table 1. A list of known proteins of human acquired enamel pellicle shown to bind CPP.

\begin{tabular}{cccc}
\hline Protein & Uniprot No. & Mw & pI \\
\hline Salivary acidic proline-rich phosphoprotein 1/2 precursor & & 11,020 & 4.14 \\
Immunoglobulin J & $\mathrm{P} 01591$ & 15,595 & 4.59 \\
Kallikrein-1 & $\mathrm{P} 06870$ & 26,406 & 4.62 \\
Cystatin-S & $\mathrm{P} 02810$ & 17,016 & 4.63 \\
Salivary acidic proline-rich phosphoprotein 1/2 precursor & $\mathrm{P} 01036$ & 14,189 & 4.83 \\
Prolactin-inducible protein & $\mathrm{P} 12273$ & 13,523 & 5.4 \\
Zinc-alpha-2-glycoprotein & $\mathrm{P} 25311$ & 32,145 & 5.58 \\
Ig kappa chain C region & $\mathrm{P} 01834$ & 11,609 & 5.58 \\
Polymeric-immunoglobulin receptor & $\mathrm{P} 01833$ & 81,349 & 5.59 \\
Serum albumin & $\mathrm{P} 02768$ & 66,472 & 5.67 \\
Protein S100-A8 & $\mathrm{P} 05109$ & 13,111 & 5.71 \\
Ig alpha-1 chain C region & $\mathrm{P} 01876$ & 37,655 & 6.08 \\
Statherin & $\mathrm{P} 02808$ & 5220 & 6.25 \\
Salivary alpha-amylase & $\mathrm{P} 04745$ & 55,910 & 6.34 \\
Carbonic anhydrase 6 & $\mathrm{P} 23280$ & 33,570 & 6.41 \\
Protein S100-A9 & $\mathrm{P} 06702$ & 10,835 & 6.5 \\
Cystatin-SN & $\mathrm{P} 01037$ & 14,316 & 6.92 \\
Histatin 1 & $\mathrm{P} 15515$ & 4848 & 8.32 \\
Cystatin-C & $\mathrm{P} 01034$ & 13,347 & 8.75 \\
Lysozyme C & $\mathrm{P} 61626$ & 14,701 & 9.28 \\
Mucin 7 & $\mathrm{Q} 8 \mathrm{TAX} 7$ & 36,809 & 9.3 \\
Submaxillary gland androgen-regulated protein 3 homolog B & $\mathrm{B} 2 \mathrm{R} 564$ & 14,117 & 10 \\
Salivary acidic proline-rich phosphoprotein 1/2 precursor & & 4371 & 12.01 \\
\hline
\end{tabular}


Table 2. A list of known peptides of human acquired enamel pellicle shown to bind CPP.

\begin{tabular}{|c|c|c|c|}
\hline Peptide/Protein & Sequence & $M_{\mathrm{w}}$ & pI \\
\hline Lactotransferrin (230-243) & ESTVFEDLSDEAER & 1616.8 & 3.77 \\
\hline Myeloperoxidase (726-741) & DFVNCSTLPALNLASW & 1746.871 & 3.8 \\
\hline Corunlin (373-383) & EQGQTQTQPGS & 1151.57 & 4 \\
\hline Protein S100a14 (13-26) & QEFSDVERAIETLI & 1638.78 & 4 \\
\hline AnnexinA1 (13-26) & FIENEEQEYVQTVK & 1749 & 4.09 \\
\hline Peroxiredoxin-5 (54-67) & APIKVGDAIPAVEV & 1370.5 & 4.37 \\
\hline Protein S100-A8 (84-93) & FWELIGEAAK & 1160.1 & 4.53 \\
\hline Statherin (1-9) & DSSEEKFLR & 1098.66 & 4.68 \\
\hline Histone H2A type 1-A (102-115) & TIAQGGVLPNIQAV & 1378.6 & 5.19 \\
\hline Protein S100-A8 (28-37) & NFHQYSVEGG & 1133.64 & 5.24 \\
\hline Statherin (11-28) & IGRFGYGYGPYQPVPEQP & 2024.96 & 6 \\
\hline Histone H2A type 1-D (89-104) & RNDEELNKLLGKVTIÂ & 1796.89 & 6.18 \\
\hline Acidic PRP \# & SPPGKPQGPPPQGGNQPQ & 1766.93 & 8.47 \\
\hline Acidic PRP \# & GPPQQGGḦQQGPPPPPPGKPQ & 2067 & 8.76 \\
\hline Con $1^{\#}$ & PQGPPPQGGSKS & 1133.3 & 9.18 \\
\hline Acidic PRP \# & GGRPQGPPQGQSPQ & 1388.61 & 9.75 \\
\hline Acidic PRP \# & GPPPQGGRPQGPPQGQSPQ & 1855.92 & 9.75 \\
\hline Acidic PRP \# & GRPQGPPQQGGHQQ & 1462.5 & 9.76 \\
\hline Acidic PRP \# & GPPQQGGHPPPPQGRPQ & 1719.9 & 9.76 \\
\hline Histatin $3^{\#}$ & DSHAKRHHGYKR & 1487.7 & 10.28 \\
\hline Histatin $3^{\#}$ & DSHAKRHHGYKRKF & 1762 & 10.45 \\
\hline Histatin 6 & DSHAKRHHGYKRKFHEKHHSHRGYR & 3191.64 & 10.62 \\
\hline Acidic PRP & GPPQQGGHPRPPR & 1379.72 & 12 \\
\hline Con 1 & GPPRPPQGGRPSRPPQ & 1656.8 & 12.3 \\
\hline
\end{tabular}

\# Numbering is ambiguous due to alternative splicing.

ELISA was used to observe the binding of $\alpha_{S 1}-\mathrm{CN}(59-79)$ and $\beta-C N(1-25)$ to adsorbed whole or parotid saliva (Figure 4). Both $\alpha_{\mathrm{S1}}-\mathrm{CN}(59-79)$ and $\beta-\mathrm{CN}$ (1-25) peptides were shown to interact with proteins derived from human saliva.

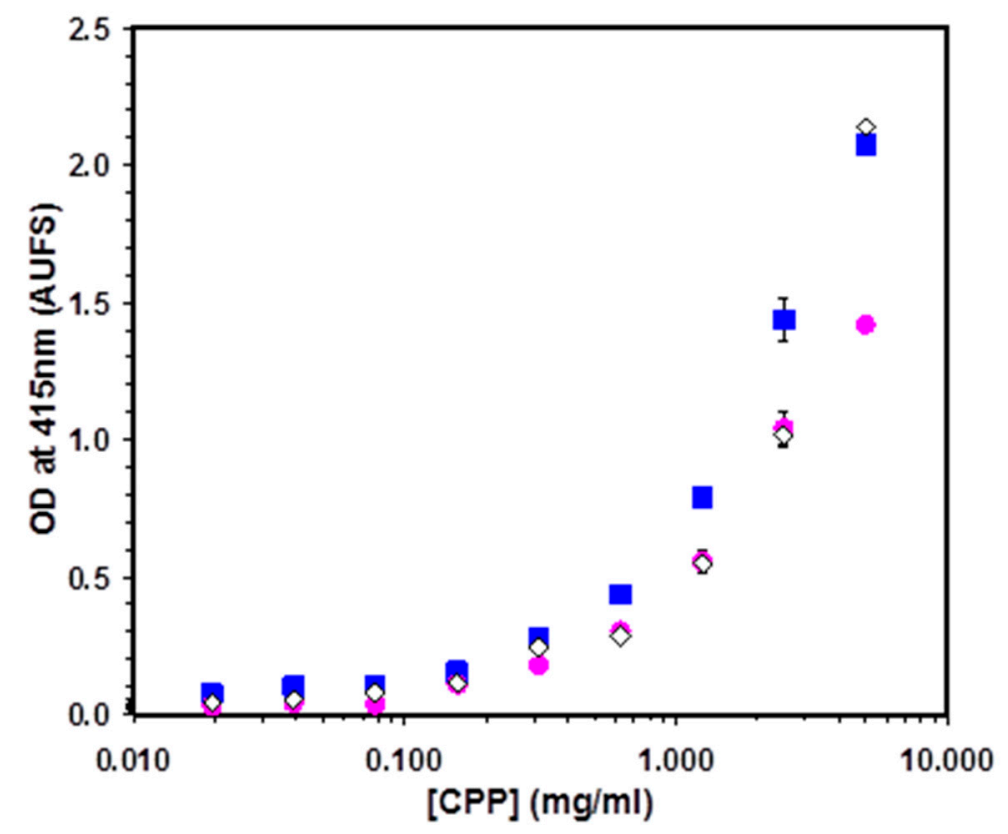

Figure 4. ELISA of $\alpha_{\mathrm{S} 1}-\mathrm{CN}$ (59-79) binding to whole saliva (blue squares) and parotid saliva (red circles) and $\beta-\mathrm{CN}(1-25)$ binding to whole saliva (white diamonds). 
To verify the binding of CPP with specific salivary proteins, ELISA was used to observe the dose response with the adsorbed salivary proteins amylase, albumin, and adsorbed peptides Histatin 1 , and statherin (Figure 5). The ELISA controls consisted of the anti-casein antibody binding directly to the salivary proteins. Differences in the dose-response curves of the $\alpha_{S 1}-\mathrm{CN}(59-79)$ and $\beta-C N(1-25)$ were interpreted as differences in affinities for the salivary protein. As observed from the affinity chromatography results, $\alpha_{\mathrm{S} 1}-\mathrm{CN}$ (59-79) displayed stronger binding than the peptide $\beta-\mathrm{CN}(1-25)$ to Histatin 1 and Statherin. In contrast to the affinity chromatography results, the $\beta-\mathrm{CN}(1-25)$ displayed stronger binding than the $\alpha_{S 1}-\mathrm{CN}$ (59-79) peptide to both amylase and albumin.
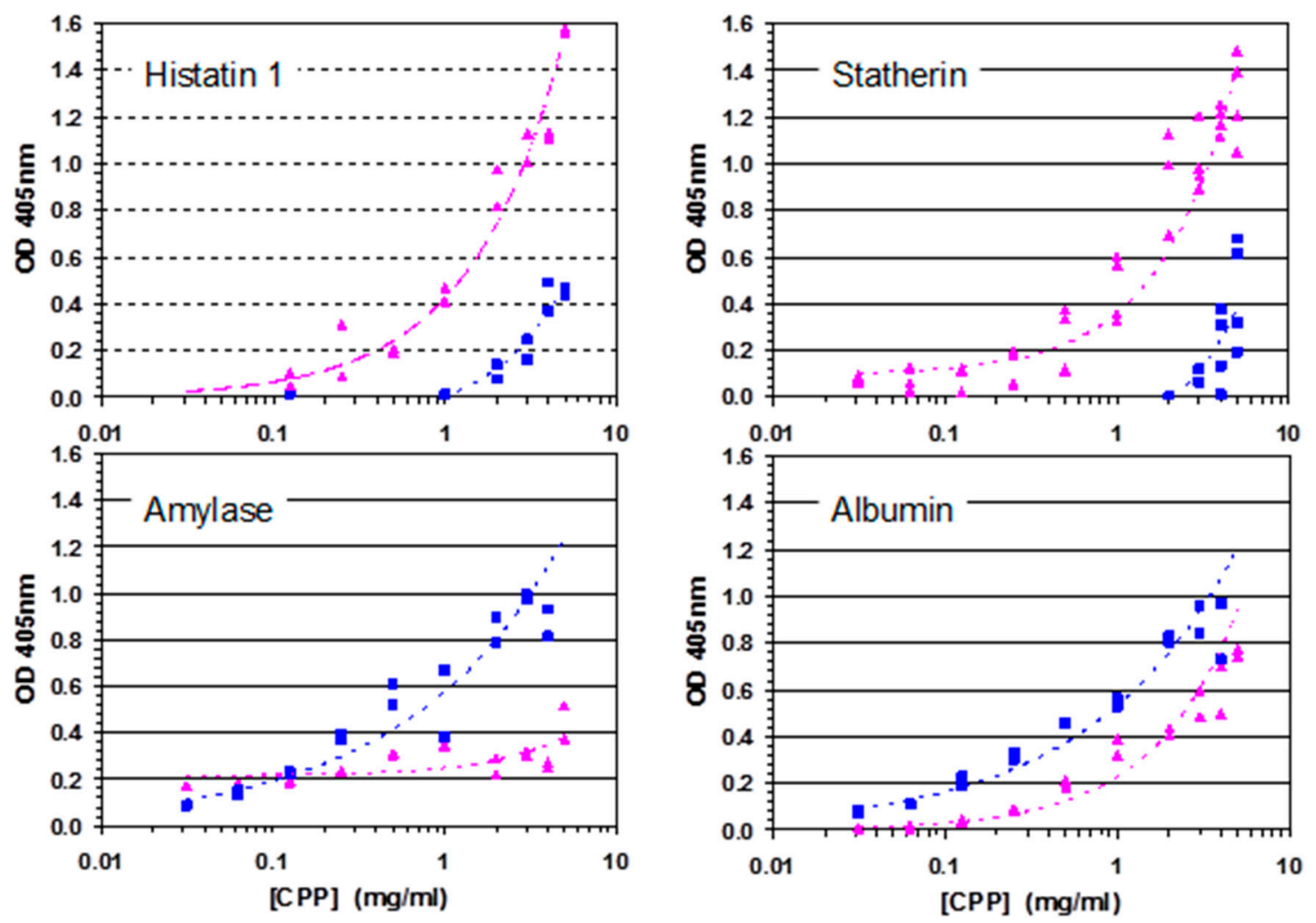

Figure 5. ELISA of $\alpha_{\mathrm{S} 1}-\mathrm{CN}$ (59-79) (triangles) and $\beta-\mathrm{CN}$ (1-25) (squares) binding to (A) Histatin 1; (B) Statherin; (C) Amylase; (D) Albumin.

\section{Discussion}

The CPP-ACP complexes commercialised as Recaldent ${ }^{\mathrm{TM}}$ are added to dental crèmes for topical application on tooth enamel surfaces to promote enamel remineralisation [15]. It is well established that the CPP and the predominant peptides $\alpha_{S 1}-\mathrm{CN}(59-79)$ and $\beta-\mathrm{CN}(1-25)$ interact with the HA mineral of the enamel both in vitro and in situ [29]. However, in the oral environment, these dental crèmes are topically applied to the enamel pellicle consisting of salivary proteins and peptides. Hence it is of interest to establish whether the CPP form any protein-protein associations with the pellicle layer to assist in providing mechanistic insight into the remineralisation process.

Initial ELISA studies confirmed that the two $\alpha_{\mathrm{S} 1}-\mathrm{CN}(59-79)$ and $\beta-\mathrm{CN}(1-25)$ peptides recognise proteins in saliva. As several salivary proteins are also phosphorylated, and the milk caseins and salivary statherins and histatins have evolved from a common ancestral gene [30]; it was essential to monitor and subtract the background binding of the antibody to the whole saliva.

This study shows that the two predominant peptides of the CPP have the ability to interact with selected salivary proteins and peptides found as components of the enamel pellicle. The sequences of both $\alpha_{\mathrm{S} 1}-\mathrm{CN}(59-79)$ and $\beta-\mathrm{CN}(1-25)$ have hydrophobic and hydrophilic regions. This enables 
them to bind to a range of proteins through hydrophobic or electrostatic interactions. Nevertheless it is evident that the CPP are not promiscuous binders of salivary proteins, but display selectivity.

The significance of this affinity for specific pellicle proteins is that the remineralisation process of early enamel lesions by CPP-ACP includes protein-protein interactions. These interactions with particular proteins/peptides may facilitate release of the cargo of calcium and phosphate ions carried by the CPP thereby facilitating the remineralisation of the underlying tooth enamel.

Previous studies have demonstrated the localisation of the CPP within supragingival plaque obtained from humans after treatment with chewing gum or mouth-rinse containing the CPP-ACP [7-9]. The CPP were visualised by immunostaining as electron-dense particles associated with the surface of bacteria as well as the intercellular matrix comprised of salivary fluid with salivary proteins and peptides. Furthermore after treatment with CPP-ACP the supragingival plaque showed an increase in both calcium and phosphate levels due to the release of the ions from the complexes as well as the presence of peptides as revealed by immunodetection [7-9]. This concomitant retention of mineral ions and peptides derived from the CPP-ACP complexes within plaque on the enamel surface can now be attributed to non-covalent interactions between specific salivary proteins and peptides and the CPP. Hence this study provides the mechanism by which CPP-ACP complexes are localised at the tooth enamel surface to deliver their cargo of calcium and phosphate ions. Fluoride's anticariogenic mechanism is based on the ion's ability to drive remineralisation of early carious lesions with fluorapatite $\left[\mathrm{Ca}_{10}\left(\mathrm{PO}_{4}\right)_{6} \mathrm{~F}_{2} ; \mathrm{FA}\right]$ [31]. As remineralisation with FA requires five calcium ions for every fluoride ion the delivery of calcium ions by the CPP-ACP helps explain the reports that $\mathrm{CPP}-\mathrm{ACP}$ and $\mathrm{F}$ have an additive effect in remineralisation of early carious lesions $[14,18]$.

In summary this study has further elucidated the mechanism of anticariogenicity displayed by the CPP-ACP nanocomplexes involving several molecular interactions between organic and inorganic molecules. These interactions include the binding of the CPP to specific salivary proteins and peptides of the enamel pellicle and supragingival plaque [7-9]; and release of calcium and phosphate ions from the nanocomplexes to the enamel subsurface lesion [15].

\section{Experimental Section}

\subsection{Purification of $\alpha_{S 1}-C N(59-79)$ and $\beta-C N(1-25)$ Peptides}

The $\alpha_{\mathrm{S} 1}-\mathrm{CN}(59-79)$ and $\beta-\mathrm{CN}(1-25)$ were purified from a CPP-ACP preparation (Mondelez International, Scoresby, Australia). CPP-ACP $(15 \mathrm{mg} / \mathrm{mL})$ in $50 \mathrm{mM}$ EDTA was run on an Agilent 1100 HPLC system using a semi-preparative C18 $5 \mu \mathrm{m}$ column $(250 \mathrm{~mm} \times 10 \mathrm{~mm}$ VYDAC). Solvent A was $0.1 \%$ TFA in deionised water and solvent $B$ was $0.1 \%$ TFA in $80 \%$ acetonitrile of HPLC grade, and $20 \%$ deionised water. The gradient applied for separation was $5 \%$ Buffer B for $1 \mathrm{~min}, 12 \%$ at $5.6 \mathrm{~min}$, $36 \%$ at $38 \mathrm{~min}, 100 \%$ at $39 \mathrm{~min}$ and $100 \%$ at $45 \mathrm{~min}$. The gradient was applied over a $45 \mathrm{~min}$ interval at a flow rate of $3.5 \mathrm{~mL} / \mathrm{min}$ with the eluent monitored at $225 \mathrm{~nm}$. Fractions corresponding to the $\alpha_{S 1}-C N(59-79)$ and $\beta-C N(1-25)$ peaks were identified on a MALDI-TOF/TOF mass spectrometer (Ultraflex TOF/TOF, Bruker Daltonics, Bremen, Germany) in the positive ion mode. These fractions were pooled, analysed for purity, lyophilised, and stored at $-80^{\circ} \mathrm{C}$.

\subsection{Preparation of Affinity Columns Based on $\alpha_{S 1}-C N$ (59-79) and $\beta-C N(1-25)$}

The $\alpha_{S 1}-\mathrm{CN}$ (59-79) and $\beta-\mathrm{CN}(1-25)$ peptides were separately dissolved in a coupling solution of $\mathrm{NaHCO}_{3}(0.1 \mathrm{M}, \mathrm{pH} 8.3)$ and $\mathrm{NaCl}(0.5 \mathrm{M})$, at a concentration of $5 \mathrm{mg} / \mathrm{mL}$. This peptide coupling solution $(1 \mathrm{~mL})$ was mixed with Sepharose $4 \mathrm{~B}$ affinity beads $(0.5 \mathrm{~g})$ which had been previously washed with cold $\mathrm{HCl}(1 \mathrm{mM})$ for the removal of preservatives. The $\mathrm{pH}$ of the solution was adjusted to 8 and coupling of the peptide to beads was achieved by mixing with end-over-end rotation for $2 \mathrm{~h}$ at room temperature. Following coupling, the beads were rinsed with $\mathrm{NaHCO}_{3}(0.1 \mathrm{M}, \mathrm{pH} 8.3$ and $\mathrm{NaCl}$ $(0.5 \mathrm{M})$ and blocked for $2 \mathrm{~h}$ at room temperature with a solution containing Tris- $\mathrm{HCl}(0.1 \mathrm{M}, \mathrm{pH} 8)$. Following blocking, beads were washed with alternating basic and acidic solutions of Tris- $\mathrm{HCl}(0.1 \mathrm{M})$ 
with $\mathrm{NaCl}(0.5 \mathrm{M})$, and Sodium acetate $(0.1 \mathrm{M})$ with $\mathrm{NaCl}(0.5 \mathrm{M}, \mathrm{pH} 3)$, respectively. Coupled beads were packed into empty columns and stored at $4{ }^{\circ} \mathrm{C}$ in ethanol $(20 \%)$.

\subsection{Adsorption and Elution of Salivary Proteins Bound to $\alpha_{S 1}-C N(59-79)$ and $\beta-C N(1-25)$ Columns}

Saliva (whole or parotid) was applied to the $\alpha_{\mathrm{S1}}-\mathrm{CN}(59-79)$ and $\beta-\mathrm{CN}(1-25)$ affinity columns several times to allow for maximum adsorption of salivary proteins to the $\alpha_{\mathrm{S} 1}-\mathrm{CN}$ (59-79) and $\beta-\mathrm{CN}$ (1-25) peptides. Un-adsorbed salivary proteins were washed off the columns with Milli-Q $\mathrm{H}_{2} \mathrm{O}$. Adsorbed salivary proteins were eluted from the columns with increasing concentrations of $\mathrm{NaCl}$ (125 $\mathrm{mM}$ to $1 \mathrm{M})$.

The masses of the salivary proteins and peptides eluted from the $\alpha_{\mathrm{S1}}-\mathrm{CN}(59-79)$ and $\beta-\mathrm{CN}(1-25)$ columns were determined by mass spectrometry [30].

\subsection{Adsorption of CPP to Hydroxyapatite}

Purified $\alpha_{\mathrm{S} 1}-\mathrm{CN}(59-79)$ and $\beta-\mathrm{CN}(1-25)(1000 \mu \mathrm{g} / \mathrm{mL})$ in $25 \mathrm{mM} \mathrm{NaCl}$ and $25 \mathrm{mM}$ imidazole buffer ( $\mathrm{pH} 7$ ) to a total volume of $1 \mathrm{~mL}$ were incubated with end-over-end rotation for $4 \mathrm{~h}$ at $37^{\circ} \mathrm{C}$ with $2 \mathrm{mg}$ of HA ( $\leqslant 200 \mathrm{~nm}$ ). Following equilibration, samples were centrifuged at $10,000 \times g$ for $15 \mathrm{~min}$ to pellet the peptide bound to HA. The supernatant containing unbound peptide was removed.

\subsection{Adsorption of Saliva to CPP-Coated Hydroxyapatite}

Whole and parotid saliva was added to HA, coated with either $\alpha_{S 1}-\mathrm{CN}$ (59-79) or $\beta-\mathrm{CN}(1-25)$. Salivary proteins were adsorbed onto hydroxyapatite with some modifications from the method of Jensen and colleagues [32]. Saliva was added to HA in a ratio of $2 \mathrm{mg} / \mathrm{mL}$, mixed and incubated with end-over-end rotation at $37^{\circ} \mathrm{C}$ for $2 \mathrm{~h}$. Following the incubation, samples were centrifuged at $14,000 \times g$ for $15 \mathrm{~min}$ at room temperature to pellet the CPP-coated HA and adsorbed salivary proteins. The supernatant was separated from the pellet, which was then washed with $0.1 \mathrm{M} \mathrm{NaCl}$.

The HA was dissolved with 0.2 M EDTA pH 7.5 and incubated for $4 \mathrm{~h}$ at $37^{\circ} \mathrm{C}$ with end-over-end rotation. After dissolution of the HA the proteins were removed from the mixture by solid phase extraction using C18 SepPak cartridges (Waters, Milford, DE, USA), as described previously. Samples were lyophilised and stored at $-80^{\circ} \mathrm{C}$. The protein/peptides of the samples were identified using mass spectrometry [30].

\subsection{Sample Preparation and SDS-PAGE}

Lyophilised samples were resuspended in Milli-Q (Merck Millipore, Bayswater, Australia) $\mathrm{H}_{2} \mathrm{O}$ $(20 \mu \mathrm{L})$. These samples were added to $4 \times$ NuPAGE $^{\circledR}$ LDS Sample Buffer $(5 \mu \mathrm{L})(106 \mathrm{mM}$ Tris HCl, $141 \mathrm{mM}$ Tris base, 2\% LDS, 10\% Glycerol, 0.51 mM EDTA, 0.22 mM SERVA $^{\circledR}$ Blue G250, $0.175 \mathrm{mM}$ Phenol Red, pH 8.5; Sigma-Aldrich, St Louis, MO, USA). NuPAGE ${ }^{\circledR}$ Reducing Agent $10 \times(2 \mu \mathrm{L})$ (Thermofisher Scientific, Melbourne, Australia) was added to the samples which were made up to a total volume of $27 \mu \mathrm{L}$. Samples were heated at $70{ }^{\circ} \mathrm{C}$ for $10 \mathrm{~min}$ for denaturation of proteins prior to loading on gels. NuPAGE ${ }^{\circledR}$ MES SDS (Thermofisher Scientific, Melbourne, Australia) running buffer was diluted from a $20 \times$ stock containing $50 \mathrm{mM} \mathrm{MES,} 50 \mathrm{mM}$ Tris base, $0.1 \%$ SDS, $1 \mathrm{mM}$ EDTA, pH 7.3. Samples and standards were loaded onto $4 \%-12 \%$ NuPAGE ${ }^{\circledR}$ Novex ${ }^{\circledR}$ Bis-Tris Mini Gels (Invitrogen, Melbourne, Australia) and electrophoresis was performed using a Novex Mini X-Cell Surelock $^{\mathrm{TM}}$ apparatus (Thermofisher Scientific, Melbourne, Australia) run at $200 \mathrm{~V}$ for $35 \mathrm{~min}$.

Gels were stained with $0.1 \%(w / v)$ Coomassie Brilliant Blue R250 in 40\% (v/v) ethanol and 10\% $(v / v)$ acetic acid, for a minimum of three hours in order to visualise the protein bands. Destaining of gels with $10 \%(v / v)$ acetic acid was carried out over 2 days for optimum development of proline-rich proteins, which are observed as pink bands following destaining with acetic acid. Electrophoretic gel bands were subjected to in-gel trypsin digestion, followed by the extraction of the tryptic peptides and subsequent analysis using RP-HPLC coupled to an ESI-TOF/TOF mass spectrometer (Bruker Daltonics, Bremen, Germany) [30]. 


\subsection{Collection of Whole and Parotid Saliva}

Approval for this study was obtained from the Ethics Committee of The Faculty of Medicine, Dentistry, and Health Sciences of The University of Melbourne (registration ID 000069.1, 2006). Informed consent was obtained from donors prior to saliva collection. Whole unstimulated saliva was collected from healthy adult male and female volunteers. Parotid saliva was collected with the use of a Lashley cup [33]. Following collection, the samples were immediately centrifuged at $14,000 \times g$ for $15 \mathrm{~min}$ at $4{ }^{\circ} \mathrm{C}$ for the removal of cell and food debris. The supernatant was collected and $5 \mu \mathrm{L}$ of Protease Inhibitor Cocktail was added per $1 \mathrm{~mL}$ of saliva supernatant to inhibit proteolytic cleavage. The samples were then immediately stored at $-70{ }^{\circ} \mathrm{C}$ until further use.

\subsection{Purification of Salivary Proteins}

Salivary histatins 1, 3, and 5, as well as statherin, were isolated from human parotid saliva according to the method of Flora [34]. Briefly, parotid saliva was made up with zinc chloride to a final concentration of $500 \mu \mathrm{M}$, and the $\mathrm{pH}$ was raised to 9.0. The samples were incubated for $20 \mathrm{~min}$ at $4{ }^{\circ} \mathrm{C}$. Following incubation, samples were centrifuged at $16,000 \times g$ for $20 \mathrm{~min}$. The supernatant was removed, and the pellet, which contained the proteins of interest, was washed with $500 \mu \mathrm{M}$ zinc chloride. Washed pellets were dissolved in Milli-Q water with the addition of $1 \mathrm{M} \mathrm{HCl}$, to a final $\mathrm{pH}$ of 2.0 and lyophilised.

Lyophilised samples were dissolved in $0.1 \%$ TFA $(v / v)$ and filtered through a $0.2 \mu \mathrm{m}$ membrane prior to being subjected to RP-HPLC. Buffer A was 0.1\% TFA in Milli-Q water, and Buffer B was 0.1\% TFA, $80 \%$ acetonitrile and $19.9 \%$ Milli-Q. A linear gradient of $0 \%-55 \%$ Buffer B was used over a $74 \mathrm{~min}$ interval, with a flow rate of $1 \mathrm{~mL} / \mathrm{min}$, and a wavelength of $230 \mathrm{~nm}$ was used to monitor the eluate. Collected peaks were lyophilised.

\subsection{ELISA}

The 96-well flat bottomed polyvinyl microtitre plates (Microtiter, Dynatech Laboratories, El Paso, TX, USA) were coated with $50 \mu \mathrm{L}$ of clarified whole saliva or parotid saliva $(10 \mu \mathrm{g} / \mathrm{mL})$ in Phosphate buffered saline (PBS) and incubated at $4{ }^{\circ} \mathrm{C}$ overnight. The excess coating solution was removed and the wells were blocked with $200 \mu \mathrm{L}$ of $1 \%(w / v)$ BSA in PBS with $0.05 \%$ Tween 20 (PBST) for $1 \mathrm{~h}$ at RT. The plate was washed four times with PBST. The CPP $\left(\left(\alpha_{S 1}-\mathrm{CN}(59-79)\right.\right.$ or $\left.\beta-\mathrm{CN}(1-25)\right)$ ( $5 \mathrm{mg} / \mathrm{mL}$ ) serially diluted in PBS was added to the wells. After incubation for $3 \mathrm{~h}$ at RT, the plate was washed four times with PBST and $50 \mu \mathrm{L}$ of polyclonal rabbit anti-bovine casein antibodies (1:640) in $0.5 \%(w / v)$ BSA was added and incubated overnight at RT. Six washes were performed with PBST. The horse radish peroxidase-conjugated goat anti-rabbit antibody $(1: 2000)(100 \mu \mathrm{L})$ in $0.5 \%$ gelatin was added to the wells. After incubation for $3 \mathrm{~h}$ at RT, the plate was washed six times with PBST. The substrate solution $(100 \mu \mathrm{L})$ was added to each well. After $15 \mathrm{~min}$ at RT, the optical density (OD) was measured at $415 \mathrm{~nm}$ using a Labsystems iEMS MF Ascent microplate reader (Pathtech Pty. Ltd., Melbourne, Australia). The salivary proteins amylase, albumin, and immobilised peptides Histatin 1, and statherin were immobilised at $10 \mu \mathrm{g} / \mathrm{mL}$ concentrations. The background OD values obtained using the anti-casein antibody binding directly to the salivary protein were subtracted from OD values obtained with the addition of CPP.

\section{Conclusions}

CPP-ACP complexes are known to inhibit enamel demineralisation and promote remineralisation of early enamel lesions [15]. During topical application of the dental crème containing the $\mathrm{CPP}-\mathrm{ACP}$ complexes, the CPP first encounter the enamel pellicle. This study shows that the peptides of the $\mathrm{CPP}-\mathrm{ACP}$ complexes are able to interact with the salivary proteins and peptides that make up the enamel pellicle. These non-covalent associations between the casein peptides and pellicle proteins and peptides have not previously been recognised as an essential step during the remineralisation process. 
Supplementary Materials: Supplementary materials can be found at http://www.mdpi.com/ $1422-0067 / 17 / 6 / 915 / \mathrm{s} 1$.

Acknowledgments: This study was supported by the Australian Government, Department of Industry, Innovation and Science.

Author Contributions: Noorjahan Laila Huq, Brent R. Ward, Keith J. Cross and Eric C. Reynolds conceived and designed the experiments. Helen Myroforidis and David P. Stanton performed the experiments. Helen Myroforidis, Brent R. Ward, Keith J. Cross, Noorjahan Laila Huq and Eric C. Reynolds analyzed the data. Eric C. Reynolds and Paul D. Veith contributed reagents/ materials/analysis tools. Noorjahan Laila Huq and Eric C. Reynolds wrote the paper.

Conflicts of Interest: The authors declare no conflict of interest. The funding sponsors had no role in the design of the study; in the collection, analyses, or interpretation of data; in the writing of the manuscript, and in the decision to publish the results.

\section{References}

1. Loesche, W. Role of Streptococcus mutans in human dental decay. Microbiol. Rev. 1986, 50, 353-380. [PubMed]

2. Featherstone, J.D.B. Dental caries: A dynamic disease process. Aust. Dent. J. 2008, 53, 286-291. [CrossRef] [PubMed]

3. Bradshaw, D.J.; Lynch, R.J. Diet and the microbial aetiology of dental caries: New paradigms. Int. Dent. J. 2013, 63, 64-72. [CrossRef] [PubMed]

4. Merritt, J.; Qi, F.; Shi, W. Milk helps build strong teeth and promotes oral health. J. Calif. Dent. Assoc. 2006, 34, 361-366. [PubMed]

5. Aimutis, W.R. Bioactive properties of milk proteins with particular focus on anticariogenesis. J. Nutr. 2004, 134, 989S-995S. [PubMed]

6. Reynolds, E.C.; Cain, C.J.; Webber, F.L.; Black, C.L.; Riley, P.F.; Johnson, I.H.; Perich, J.W. Anticariogenicity of calcium phosphate complexes of tryptic casein phosphopeptides in the rat. J. Dent. Res. 1995, 74, 1272-1279. [CrossRef] [PubMed]

7. Reeves, R.E.; Latour, N.G. Calcium phosphate sequestering phosphopeptide from casein. Science 1958, 128, 472. [CrossRef] [PubMed]

8. Swaisgood, H.E. Chemistry of milk protein. Dev. Dairy Chem. 1982, 1, 1-59.

9. Reynolds, E.C.; Cai, F.; Shen, P.; Walker, G.D. Retention in plaque and remineralization of enamel lesions by various forms of calcium in a mouthrinse or sugar-free chewing gum. J. Dent. Res. 2003, 82, 206-211. [CrossRef] [PubMed]

10. Cross, K.J.; Huq, N.L.; Palamara, J.E.; Perich, J.W.; Reynolds, E.C. Physicochemical characterization of casein phosphopeptide-amorphous calcium phosphate nanocomplexes. J. Biol. Chem. 2005, 280, 15362-15369. [CrossRef] [PubMed]

11. Cochrane, N.J.; Saranathan, S.; Cai, F.; Cross, K.J.; Reynolds, E.C. Enamel subsurface lesion remineralisation with casein phosphopeptide stabilised solutions of calcium, phosphate and fluoride. Caries Res. 2008, 42, 88-97. [CrossRef] [PubMed]

12. Reynolds, E.C. Remineralization of enamel subsurface lesions by casein phosphopeptide-stabilized calcium phosphate solutions. J. Dent. Res. 1997, 76, 1587-1595. [CrossRef] [PubMed]

13. Cross, K.J.; Huq, N.L.; Reynolds, E.C. Casein phosphopeptides in oral health-Chemistry and clinical applications. Curr. Pharm. Des. 2007, 13, 793-800. [CrossRef] [PubMed]

14. Reynolds, E.C.; Cai, F.; Cochrane, N.J.; Shen, P.; Walker, G.D.; Morgan, M.V.; Reynolds, C. Fluoride and casein phosphopeptide-amorphous calcium phosphate. J. Dent. Res. 2008, 87, 344-348. [CrossRef] [PubMed]

15. Cochrane, N.J.; Cai, F.; Huq, N.L.; Burrow, M.F.; Reynolds, E.C. New approaches to enhanced remineralization of tooth enamel. J. Dent. Res. 2010, 89, 1187-1197. [CrossRef] [PubMed]

16. Morgan, M.V.; Adams, G.G.; Bailey, D.L.; Tsao, C.E.; Fischman, S.L.; Reynolds, E.C. The anticariogenic effect of sugar-free gum containing CPP-ACP nanocomplexes on approximal caries determined using digital bitewing radiography. Caries Res. 2008, 42, 171-184. [CrossRef] [PubMed]

17. Yengopal, V.; Mickenautsch, S. Caries preventive effect of casein phosphopeptide-amorphous calcium phosphate (CPP-ACP): A meta-analysis. Acta Odontol. Scand. 2009, 67, 321-332. [CrossRef] [PubMed]

18. Cochrane, N.J.; Reynolds, E.C. Calcium phosphopeptides-Mechanisms of action and evidence for clinical efficacy. Adv. Dent. Res. 2012, 24, 41-47. [CrossRef] [PubMed] 
19. Lendenmann, U.; Grogan, J.; Oppenheim, F.G. Saliva and dental pellicle-A review. Adv. Dent. Res. 2000, 14, 22-28. [CrossRef] [PubMed]

20. Zimmerman, J.N.; Custodio, W.; Hatibovic-Kofman, S.; Lee, Y.H.; Xiao, Y.; Siqueira, W.L. Proteome and peptidome of human acquired enamel pellicle on deciduous teeth. Int. J. Mol. Sci. 2013, 14, 920-934. [CrossRef] [PubMed]

21. Siqueira, W.L.; Zhang, W.M.; Helmerhorst, E.J.; Gygi, S.P.; Oppenheim, F.G. Identification of protein components in in vivo human acquired enamel pellicle using LC-ESI-MS/MS. J. Proteome Res. 2007, 6, 2152-2160. [CrossRef] [PubMed]

22. Siqueira, W.L.; Oppenheim, F.G. Small molecular weight proteins/peptides present in the in vivo formed human acquired enamel pellicle. Arch. Oral Biol. 2009, 54, 437-444. [CrossRef] [PubMed]

23. Vitorino, R.; Calheiros-Lobo, M.J.; Duarte, J.A.; Domingues, P.M.; Amado, F.M.L. Peptide profile of human acquired enamel pellicle using MALDI tandem MS. J. Sep. Sci. 2008, 31, 523-537. [CrossRef] [PubMed]

24. Vitorino, R.; Calheiros-Lobo, M.J.; Williams, J.; Ferrer-Correia, A.J.; Tomer, K.B.; Duarte, J.A.; Domingues, P.M.; Amado, F.M. Peptidomic analysis of human acquired enamel pellicle. Biomed. Chromatogr. 2007, 21, 1107-1117. [CrossRef] [PubMed]

25. Vitorino, R.; de Morais Guedes, S.; Ferreira, R.; Lobo, M.J.; Duarte, J.; Ferrer-Correia, A.J.; Tomer, K.B.; Domingues, P.M.; Amado, F.M. Two-dimensional electrophoresis study of in vitro pellicle formation and dental caries susceptibility. Eur. J. Oral Sci. 2006, 114, 147-153. [CrossRef] [PubMed]

26. Vitorino, R.; Lobo, M.J.; Duarte, J.; Ferrer-Correia, A.J.; Tomer, K.B.; Dubin, J.R.; Domingues, P.M.; Amado, F.M. In vitro hydroxyapatite adsorbed salivary proteins. Biochem. Biophys. Res. Commun. 2004, 320, 342-346. [CrossRef] [PubMed]

27. Yao, Y.; Berg, E.A.; Costello, C.E.; Troxler, R.F.; Oppenheim, F.G. Identification of protein components in human acquired enamel pellicle and whole saliva using novel proteomics approaches. J. Biol. Chem. 2003, 278, 5300-5308. [CrossRef] [PubMed]

28. Yao, Y.; Grogan, J.; Zehnder, M.; Lendenmann, U.; Nam, B.; Wu, Z.; Costello, C.E.; Oppenheim, F.G. Compositional analysis of human acquired enamel pellicle by mass spectrometry. Arch. Oral Biol. 2001, 46, 293-303. [CrossRef]

29. Cross, K.J.; Huq, N.L.; O’Brien-Simpson, N.M.; Perich, J.W.; Attard, T.J.; Reynolds, E.C. The role of multiphosphorylated peptides in mineralized tissue regeneration. Int. J. Pept. Res. Ther. 2007, 13, 479-495. [CrossRef]

30. Huq, N.L.; Cross, K.J.; Ung, M.; Myroforidis, H.; Veith, P.D.; Chen, D.; Stanton, D.; He, H.; Ward, B.R.; Reynolds, E.C. A review of the salivary proteome and peptidome and saliva-derived peptide therapeutics. Int. J. Pept. Res. Ther. 2007, 13, 547-564. [CrossRef]

31. Rölla, G.; Ekstrand, J. Fluoride in oral fluids and dental plaque. In Fluoride in Dentistry; Fejerskov, O., Burt, B.A., Eds.; Munksgaard: Copenhagen, Denmark, 1996; pp. 215-229.

32. Jensen, J.L.; Lamkin, M.S.; Oppenheim, F.G. Adsorption of human salivary proteins to hydroxyapatite: A comparison between whole saliva and glandular salivary secretions. J. Dent. Res. 1992, 71, 1569-1576. [CrossRef] [PubMed]

33. Denny, P.; Hagen, F.K.; Hardt, M.; Liao, L.; Yan, W.; Arellanno, M.; Bassilian, S.; Bedi, G.S.; Boontheung, P.; Cociorva, D.; et al. The proteomes of human parotid and submandibular/sublingual gland salivas collected as the ductal secretions. J. Proteome Res. 2008, 7, 1994-2006. [CrossRef] [PubMed]

34. Flora, B.; Gusman, H.; Helmerhorst, E.J.; Troxler, R.F.; Oppenheim, F.G. A new method for the isolation of histatins 1, 3, and 5 from parotid secretion using zinc precipitation. Protein Expr. Purif. 2001, 23, 198-206. [CrossRef] [PubMed]

(C) 2016 by the authors; licensee MDPI, Basel, Switzerland. This article is an open access article distributed under the terms and conditions of the Creative Commons Attribution (CC-BY) license (http:/ / creativecommons.org/licenses/by/4.0/). 